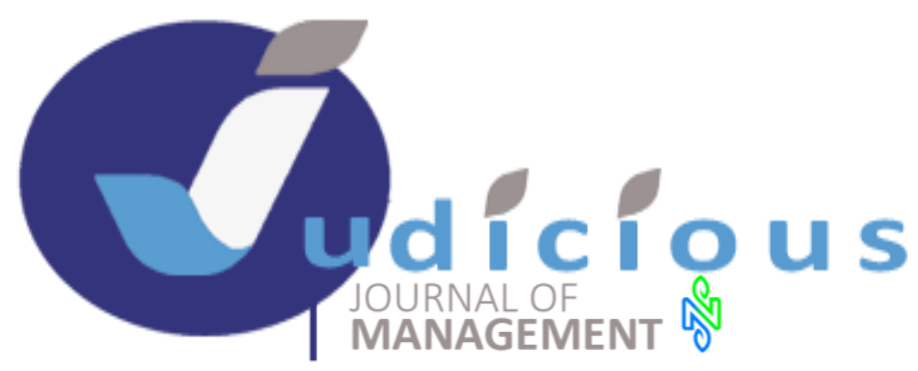

\title{
ANALISIS PENGARUH KUALITAS PELAYANAN, KEPERCAYAAN, PERCEIVED VALUE DAN KEPUASAN MAHASISWA TERHADAP LOYALITAS MAHASISWA
}

\author{
Dewi Murtiningsih \\ Universitas Budi Luhur \\ Jakarta Selatan, Indonesia \\ dewi.murtiningsih@budiluhur.ac.id
}

\author{
Widi Wahyudi \\ Universitas Budi Luhur \\ Jakarta Selatan, Indonesia \\ widi.wahyudi@budiluhur.ac.id
}

\begin{abstract}
Abstrak
Penelitian ini bertujuan untuk mengetahui Untuk mengetahui pengaruh kualitas pelayanan terhadap loyalitas mahasiswa; Untuk mengetahui pengaruh kepercayaan terhadap loyalitas mahasiswa; Untuk mengetahui perceive value terhadap loyalitas mahasiswa; Untuk mengetahui pengaruh kepuasan mahasiswa terhadap loyalitas mahasiswa; Untuk mengetahui pengaruh kualitas layanan, kepercayaan, perceived value kepuasan mahasiswa terhadap loyalitas mahasiswa. Penelitian ini termasuk dalam jenis explanatory research. Sampel dalam penelitian ini berjumlah 100 mahasiswa. Kuesioner digunakan sebagai alat untuk mengambil data responden, yang kemudian diuji menggunakan uji validitas dan reliabilitas. Alat analisis yang digunakan yaitu analisis regresi linear dengan software SPSS Versi 21. Hasil penelitian menunjukkan bahwa kualitas pelayanan tidak berpengaruh terhadap loyalitas mahasiswa, kepercayaan tidak berpengaruh terhadap loyalitas mahasiswa, perceived value tidak berpengaruh. terhadap loyalitas mahasiswa, kepuasan mahasiswa berpengaruh terhadap loyalitas mahasiswa, dan untuk mengetahui secara simultan kualitas layanan, kepercayaan, perceived value dan kepuasan mahasiswa berpengaruh terhadap loyalitas mahasiswa.
\end{abstract}

Kata Kunci: kualitas layanan, kepercayaan, perceived value, kepuasan mahasiswa, loyalitas mahasiswa

\section{PENDAHULUAN}

Di dunia pendidikan, perguruan tinggi atau universitas dapat dipandang sebagai pihak penyedia jasa atau layanan, Siswa, di sisi lain, dianggap sebagai pengguna layanan atau layanan yang disebut konsumen atau pelanggan. Layanan pendidikan dikategorikan sebagai layanan murni atau layanan kontak tinggi. Artinya, ketika layanan diberikan, siswa menjadi bagian dari sistem (pendidikan) dan ada tingkat kontak yang tinggi antara siswa dan penyedia layanan. Lembaga pendidikan, khususnya universitas, menawarkan lebih dari satu jenis layanan. Layanan utama biasanya adalah layanan pembelajaran atau pembelajaran, tetapi layanan lain seperti layanan administrasi akademik, saran/konseling, perpustakaan, laboratorium, internet/komputer, kafetaria, fasilitas penelitian dan olahraga juga merupakan bagian yang tidak terpisahkan dari layanan pendidikan. Dikutip dari Zahir dan Saputra, 2018). Kotler dan Armstrong (2007) menemukan bahwa 4.444 perusahaan jasa, seperti rumah sakit dan kantor pos, termasuk lembaga pendidikan. Lembaga ini memiliki 4.444 pelanggan, termasuk mahasiswa, karyawan, dosen, staf, lulusan, penyandang dana, dan industri yang menerima lulusan. Lembaga pendidikan dikenal sebagai produsen jasa pendidikan, dan masyarakat mengharapkan kualitas talenta melalui sistem kampus dan proses pembelajaran. Kualitas pendidikan merupakan faktor kunci untuk menciptakan keunggulan kompetitif nasional. Kualitas pendidikan memang tidak terlihat, namun dampaknya dapat dilihat dan dirasakan di banyak bidang. Institusi pendidikan yang dapat 
menghasilkan lulusan berkualitas tinggi diakui atas kepuasan mahasiswanya, peningkatan pelamar (applicants for acceptance), dan peningkatan rekrutmen lulusan dari berbagai perusahaan nirlaba. Serta akuntabilitas negara dan lembaga terkait (Putra dan Yasa, dikutip dari 2015).

Kondisi persaingan yang ketat merupakan salah faktor yang harus diperhatikan oleh manajemen perguruan tinggi swasta (PTS) yaitu kepuasan yang diperoleh mahasiswa terhadap pelayanan. Universitas sebagai institusi yang memberikan layanan kepada mahasiswa dan masyarakat dituntut untuk memberikan layanan yang makin lama makin lebih baik, lebih baru, lebih cepat dengan prosedur yang sesederhana dan tidak berbelit. Kita harus tau hal-hal apa saja yang dianggap penting oleh mahasiswa, dan kita berusaha untuk menghasilkan kinerja sebaik mungkin sehingga dapat menghasilkan pelayanan yang memuaskan sesuai dengan keinginan mahasiswa (Dikutip dari Setiyati, 2013).

Reseacrh gap dalam penelitian ini adalah Penelitian yang dilakukan oleh Cristobal, et al. (2007) menunjukkan kualitas pelayanan tidak berpengaruh secara signifikan terhadap loyalitas. Sedangkan penelitian yang dilakukan oleh Erwin dan Sitinjak (2017) menyatakan bahwa kepercayaan tidak berpengaruh terhadap loyalitas. Kemudian Kurniawan (2013) melalukan penelitian dengan hasil tidak terdapat pengaruh antara nilai pelanggan terhadap loyalitas. Sedangkan penelitian yang dilakukan oleh Tanisah dan Maftuhah (2015) menyatakan bahwa kepuasan tidak berpengaruh positif terhadap loyalitas.

Berdasarkan research gap tersebut dan masih adanya inkonsistensi hasil penelitian, maka peneliti tertarik untuk melakukan penelitian ini dengan objek yang berbeda. Sasaran responden dalam penelitian ini adalah mahasiswa yang minimal semester 2 yang sedang berkuliah di Program Studi Manajemen Fakultas Ekonomi dan Bisnis Universitas Budi Luhur Jakarta mengambil jenjang strata satu (S1). Berdasarkan alasan tersebut di atas maka perlu dikaji lebih jauh tentang "Analisis Pengaruh Kualitas Layanan, Kepercayaan, perceived value, dan kepuasan mahasiswa terhadap loyalitas mahasiswa".

Kualitas pelayanan merupakan faktor utama yang mempengaruhi loyalitas pelanggan dikarenakan pelanggan yang terpuaskan nilai pribadinya dan mengalami mood yang positif terhadap pelayanan akan memiliki loyalitas yang tinggi terhadap perusahaan tersebut. Pelanggan sering kali tidak loyal disebabkan oleh adanya pelayanan yang buruk atau kualitas pelayanan yang semakin menurun dari yang diharapkan pelanggan. Penelitian yang dilakukan oleh Starini (2013) menyatakan bahwa kualitas pelayanan berpengaruh positif dan signifikan terhadap loyalitas pelanggan. Kemudian Smertana (2016) melakukan penelitian dan menunjukkan bahwa kualitas layanan berpengaruh terhadap loyalitas. Putri (2017) melakukan penelitian bahwa kualitas layanan berpengaruh terhadap loyalitas. Berdasarkan pendapat tersebut, maka dapat disusun hipotesis dalam penelitian ini adalah: $\mathrm{H}_{1}$ : Kualitas layanan berpengaruh terhadap loyalitas mahasiswa.

Penelitian yang dilakukan oleh Tumbel (2016) menyatakan bahwa kepercayaan berpengaruh terhadap loyalitas, sedangkan penelitian yang dilakukan oleh Harumi (2016) menyatakan bahwa kepercayaan berpengaruh terhadap loyalitas. Kemudian Hairany dan Sangen (2014) melalukan penelitian dengan hasil bahwa kepercayaan berpengaruh signifikan positif terhadap loyalitas. Penelitian yang dilakukan oleh Bahrudii dan Zuhro (2015) menunjukkan bahwa kepercayaan berpengaruh terhadap loyalitas. Berdasarkan hasil dasar penelitian terdahulu, maka hipotesis dalam penelitian ini adalah sebagai berikut: $\mathrm{H}_{2}$ : Kepercayaan berpengaruh terhadap loyalitas mahasiswa.

Nilai yang diterima pelanggan adalah imbalan yang diterima pelanggan atas kualitas dan pengorbanan yang mendorong mereka untuk menggunakan layanan yang mereka berikan (Lee, 2010). Survei dilakukan oleh Ishaq (2012). Auka (2012), dan Chen dan Tsai (2008). Hal ini menunjukkan bahwa nilai yang diterima dari pelanggan berpengaruh signifikan terhadap loyalitas pelanggan. Oleh karena itu, hipotesis keempat dapat ditetapkan sebagai berikut: H3: Nilai yang dirasakan mempengaruhi loyalitas siswa. 
Menurut Kurniawati (2014), menunjukkan bahwa kepuasan konsumen berpengaruh positif dan signifikan terhadap loyalitas pelanggan. Penelitian yang dilakukan oleh Kemudian penelitian yang dilakukan oleh Haryati Hatta (2017) menunjukkan bahwa kepuasan berpengaruh terhadap loyalitas. Indarto et al., (2018) pada risetnya menyatakan kepuasan berpengaruh terhadap loyalitas. Dan penelitian yang dilakukan oleh Sumertana (2016) membuktikan bahwa kepuasan berpengaruh terhadap loyalitas. Berdasarkan pendapat tersebut, maka hipotesis dalam penelitian ini adalah sebagai berikut: $\mathrm{H}_{4}$ : Kepuasan mahasiswa berpengaruh terhadap loyalitas mahasiswa.

Berdasarkan penelitian yang dilakukan oleh Starini (2013), Sumetana (2016) dan Putri (2017) menyatakan bahwa kualitas pelayanan berpengaruh positif dan signifikan terhadap loyalitas pelanggan. Kemudian penelitian yang dilakukan oleh Tumbel (2016), Harumi (2016), Hairany dan Sangen (2014) serta Bahrudin dan Zuhro (2015) menyatakan bahwa kepercayaan berpengaruh terhadap loyalitas. Penelitian yang dilakukan oleh Ishaq (2012); Auka (2012); dan Chen dan Tsai (2008) menunjukkan nilai yang diterima pelanggan berpengaruh secara signifikan terhadap loyalitas pelanggan. Kurniawati (2014), Haryati Hatta (2017), Indarti et al., (2018) serta Sumertana (206) menunjukkan bahwa kepuasan konsumen berpengaruh positif dan signifikan terhadap loyalitas pelanggan. Berdasarkan pendapat tersebut, maka hipotesis dalam penelitian ini adalah sebagai berikut $: \mathrm{H}_{5}$ : Kualitas layanan, kepercayaan dan kepuasan mahasiswa berpengaruh terhadap loyalitas mahasiswa.

\section{METODE}

Bagian Penelitian ini termasuk dalam kategori explanatory research. Populasi dalam penelitian ini adalah Seluruh mahasiswa yang menggunakan jasa Universitas Budi Luhur yaitu mahasiswa di Program Studi Manajemen, Fakultas Ekonomi dan Bisnis. Sampel dalam penelitian ini berjumlah 110 responden. Teknik pengambilan sampel menggunakan teknik proportional sampling. Data didapatkan dengan menyebarkan kuesioner. Analisis data menggunakan SPSS Versi 22.

\section{HASIL DAN PEMBAHASAN}

\section{Hasil}

Bagian ini Uji asumsi klasik yang berupa uji normalitas, multikolinearitas, dan heterokidatisitas sudah terpenuhi serta uji korelasinya juga berhubungan, berikut akan dibahas terkait uji regresinya.

Regresi Linier Berganda bertujuan untuk menguji pengaruh antara satu variabel dengan variabel lain dan melihat hasil nilai dari variabel yang telah diteliti apakah bernilai positif atau negatif. Pengujian hipotesis digunakan untuk menguji pengaruh kualitas pelayanan dan biaya kuliah terhadap kepuasan mahasiswa.

Coefficients $^{\mathrm{a}}$

Tabel 1. Hasil Analisis Regresi Linier Berganda-Metode Enter

\begin{tabular}{|c|c|c|c|c|c|c|}
\hline \multirow[t]{2}{*}{ Model } & & \multicolumn{2}{|c|}{ Unstandardized Coefficients } & \multirow{2}{*}{$\begin{array}{l}\text { Standardized } \\
\text { Coefficients } \\
\text { Beta }\end{array}$} & \multirow[t]{2}{*}{$\mathrm{t}$} & \multirow[t]{2}{*}{ Sig. } \\
\hline & (Constant) & $\begin{array}{l}\text { B } \\
-4.040\end{array}$ & $\begin{array}{l}\text { Std. Error } \\
1.478\end{array}$ & & & \\
\hline 1 & $\begin{array}{l}\text { SQ } \\
B\end{array}$ & $\begin{array}{l}.405 \\
.243\end{array}$ & $\begin{array}{l}.060 \\
.051\end{array}$ & $\begin{array}{l}.526 \\
.375\end{array}$ & $\begin{array}{l}6.715 \\
4.782\end{array}$ & $\begin{array}{l}.000 \\
.000\end{array}$ \\
\hline
\end{tabular}

a. Dependent Variable: KM

Sumber: Hasil Output SPSS 22 (2021) 
Berdasarkan Tabel 1 di atas diketahui persamaan regresi yang terbentuk yaitu:

$\mathrm{Y}=\alpha+\beta_{1} \mathrm{X}_{1}+\beta_{2} \mathrm{X}_{2}+\beta_{3} \mathrm{X}_{3}+\beta_{4} \mathrm{X}_{4}+e$

$\mathrm{Y}=4.665+0.135 \mathrm{X}_{1}-0.086 \mathrm{X}_{2}+0.094 \mathrm{X}_{3}+0.313 \mathrm{X}_{4}$

Di mana:

$\mathrm{Y}=$ Loyalitas Mahasiswa

$\mathrm{X}_{1} \quad=$ Variabel Kualitas Layanan

$\mathrm{X}_{2} \quad=$ Variabel Kepercayaan

$\mathrm{X}_{3} \quad=$ Variabel Perceived Value

$\mathrm{X}_{4} \quad=$ Variabel Kepuasan Mahasiswa

$\alpha \quad=$ Konstanta

$\beta_{1} \quad=$ Angka koefisien Regresi Pertama

$\beta_{2} \quad=$ Angka koefisien Regresi Kedua

e $\quad$ Standard Error

Persamaan regresi tersebut di atas dapat diinterpretasikan sebagai berikut:

1. Konstanta -0.4040 artinya : Jika kualitas pelayanan dan biaya kuliah nilainya 0 atau tidak memiliki pengaruh, maka kepuasan mahasiswa nilainya sebesar -4.040 .

2. Koefisien regresi variabel kualitas pelayanan $\left(\beta_{1}\right)$ bernilai positif, yaitu 0.405 ini dapat diartikan bahwa setiap peningkatan kualitas pelayanan sebesar 1, maka akan menaikkan kepuasan mahasiswa sebesar 0.405 .

3. Koefisien regresi variabel biaya kuliah $\left(\beta_{2}\right)$ bernilai positif, yaitu 0.243 ini dapat diartikan bahwa setiap peningkatan biaya kuliah sebesar 1, maka akan meningkatkan kepuasan mahasiswa sebesar 0.243 .

Koefisien Determinasi digunakan untuk mengetahui besarnya kontribusi pengaruh variabel kualitas pelayanan dan biaya kuliah terhadap kepuasan mahasiswa.

\section{Tabel 2. Koefisien Determinasi}

\begin{tabular}{llll}
\multicolumn{4}{c}{ Model Summary $^{\mathbf{b}}$} \\
\hline Model $\mathrm{R}$ & $\mathrm{R}$ Square & $\begin{array}{c}\text { Adjusted R Square Std. Error of the } \\
\text { Estimate }\end{array}$ \\
\hline $1 \quad .845^{\mathrm{a}}$ & .715 & .709 & 2.407 \\
\hline $\begin{array}{l}\text { a. Predictors: (Constant), B, SQ } \\
\text { b. Dependent Variable: KM }\end{array}$ \\
Sumber: Hasil Output SPSS 22 (2021)
\end{tabular}

Pada Tabel 2 dapat dilihat bahwa nilai R 0.845 mendekati angka 1, sehingga dapat dikatakan bahwa hubungan antara kualitas pelayanan dan biaya kuliah terhadap kepuasan mahasiswa cukup erat. Untuk koefisien determinasi atau Adjusted $R$ Square sebesar 0.715 atau $71.5 \%$, angka tersebut berarti $71.5 \%$ kepuasan mahasiswa dipengaruhi oleh kualitas pelayanan dan biaya kuliah sedangkan sisanya sebesar 28.5\% dipengaruhi oleh faktor-faktor lain yang tidak termasuk dalam penelitian ini. Std Error of the Estimate 2.407, artinya kesalahan yang dapat terjadi dalam memprediksi kepuasan mahasiswa sebesar 2.40 .

Uji hipotesis parsial koefisien (uji t) dilakukan untuk mengetahui apakah variabel bebas secara parsial (sendiri-sendiri) ada pengaruh terhadap variabel terikat. Uji parsial dilakukan dengan membandingkan $t$ hitung dengan $t$ tabel sehingga sering disebut uji t. Degree of Freedom pada uji $t$ adalah n-k-1 di mana $\mathrm{n}$ (jumlah data) dan $\mathrm{k}$ (jumlah variabel independen). 
Coefficients $^{\mathrm{a}}$

Tabel 3. Uji Hipotesis Parsial Koefisien (Uji t)

\begin{tabular}{|c|c|c|c|c|c|c|}
\hline \multirow{2}{*}{\multicolumn{2}{|c|}{ Model }} & \multicolumn{2}{|c|}{ Unstandardized Coefficients } & \multirow{2}{*}{$\begin{array}{l}\text { Standardized } \\
\text { Coefficients } \\
\text { Beta }\end{array}$} & \multirow[t]{2}{*}{$\mathrm{t}$} & \multirow[t]{2}{*}{ Sig. } \\
\hline & & $\mathrm{B}$ & Std. Error & & & \\
\hline & (Constant) & 4.665 & 2.517 & & 1.853 & .067 \\
\hline & Kualitas Pelayanan & .135 & .072 & .223 & 1.865 & .065 \\
\hline \multirow[t]{3}{*}{1} & Kepercayaan & -.086 & .085 & -.128 & -1.016 & .312 \\
\hline & Perceived Value & .094 & .078 & .129 & 1.199 & .233 \\
\hline & Kepuasan Mahasiswa & .313 & .097 & .332 & 3.218 & .002 \\
\hline
\end{tabular}

a. Dependent Variable: Loyaltitas Mahasiswa

Sumber: Hasil Output SPSS 21 (2021)

Dari Tabel 3, di atas dapat disimpulkan bahwa:

1. Variabel kualitas pelayanan (t hitung $=1.865 ;$ Sig $=0.065)$ maka $\mathrm{H}_{0}$ diterima, $\mathrm{H}_{\mathrm{a}}$ ditolak dan signifikansi lebih dari 0.05 (0.065 lebih dari 0.05) maka $\mathrm{H}_{\mathrm{a}}$ diterima, $\mathrm{H}_{0}$ ditolak jadi dapat disimpulkan bahwa variabel kualitas layanan secara parsial tidak mempengaruhi variabel loyalitas mahasiswa.

2. Variabel kepercayaan ( $\mathrm{t}$ hitung $=-1.016 ; \mathrm{Sig}=0.312)$ maka $\mathrm{H}_{0}$ diterima, $\mathrm{H}_{\mathrm{a}}$ ditolak dan signifikansi lebih dari 0.05 (0.312 lebih dari 0.05) maka $\mathrm{H}_{\mathrm{a}}$ diterima, $\mathrm{H}_{0}$ ditolak jadi dapat disimpulkan bahwa variabel kepercayaan secara parsial tidak mempengaruhi variabel loyalitas mahasiswa.

3. Variabel perceived value ( $\mathrm{t}$ hitung $=1.199 ;$ Sig $=0.233)$ maka $\mathrm{H}_{0}$ diterima, $\mathrm{H}_{\mathrm{a}}$ ditolak dan signifikansi kurang dari $0.05(0.233$ lebih dari 0.05$)$ maka $\mathrm{H}_{\mathrm{a}}$ diterima, $\mathrm{H}_{0}$ ditolak jadi dapat disimpulkan bahwa variabel perceived value secara parsial tidak mempengaruhi variabel loyalitas mahasiswa.

4. Variabel kepuasan mahasiswa ( $\mathrm{t}$ hitung $=3.218$; Sig $=0.002)$ maka $\mathrm{H}_{0}$ ditolak, $\mathrm{H}_{\mathrm{a}}$ diterima dan signifikansi kurang dari 0.05 (0.000 kurang dari 0.05) maka $\mathrm{H}_{\mathrm{a}}$ diterima, $\mathrm{H}_{0}$ ditolak jadi dapat disimpulkan bahwa variabel kepuasan mahasiswa secara parsial mempengaruhi variabel loyalitas mahasiswa.

Uji simultan koefisien regresi dilakukan untuk mengetahui apakah variabel bebas secara simultan (bersama-sama) ada pengaruh signifikan terhadap variabel terikat. Pengujian persamaan secara simultan dilakukan dengan melakukan perbandingan antara $\mathrm{F}$ hitung dengan $\mathrm{F}$ tabel.

\section{Tabel 4. Uji Hipotesis Simultan Koefisien (Uji F)}

ANOVA $^{\mathrm{a}}$

\begin{tabular}{lllllll}
\hline Model & & Sum of Squares & df & Mean Square & F & Sig. \\
\hline \multirow{4}{*}{1} & Regression & 69.046 & 4 & 17.261 & 6.080 & $.000^{\mathrm{b}}$ \\
& Residual & 269.714 & 95 & 2.839 & & \\
& Total & 338.760 & 99 & & & \\
\hline
\end{tabular}

a. Dependent Variable: Loyaltitas Mahasiswa

b. Predictors: (Constant), Kepuasan Mahasiswa, Kualitas Pelayanan, Perceived Value, Kepercayaan

Sumber: Hasil Output SPSS 21 (2021)

Nilai prob F hitung ( $\mathrm{sig}$ ) pada Tabel 4 nilainya 0.000 lebih kecil dari tingkat kesalahan $(0.05)$ sehingga dapat disimpulkan bahwa model regresi linear yang di estimasi layak digunakan untuk menjelaskan pengaruh kualitas pelayanan, kepercayaan, perceived value dan kepuasan mahasiswa terhadap loyalitas mahasiswa. 


\section{Pembahasan}

Hasil analisa menunjukkan bahwa kualitas pelayanan tidak berpengaruh terhadap loyalitas mahasiswa pada mahasiswa di Prodi Manajemen Fakultas Ekonomi dan Bisnis UBL. Fakta empiris menunjukkan bahwa indikator dari variabel kualitas pelayanan yang memiliki nilai rata-rata terkecil yaitu dari indikator E151 yaitu emphaty dengan nilai sebesar 3.85 yang direfleksikan dengan item Staf dan Dosen di Program Studi Manajemen Fakultas Ekonomi dan Bisnis Universitas Budi Luhur menjaga hubungan baik dengan konsumen, masih di persepsikan rendah oleh responden. Penelitian ini tidak sejalan dengan penelitian yang dilakukan oleh Starini (2013) menyatakan bahwa kualitas pelayanan berpengaruh positif dan signifikan terhadap loyalitas pelanggan. Kemudian Smertana (2016) melakukan penelitian dan menunjukkan bahwa kualitas layanan berpengaruh terhadap loyalitas. Putri (2017) melakukan penelitian bahwa kualitas layanan berpengaruh terhadap loyalitas.

Hasil analisa menunjukkan bahwa kepercayaan tidak berpengaruh terhadap loyalitas mahasiswa pada mahasiswa di Prodi Manajemen Fakultas Ekonomi dan Bisnis UBL. Fakta empiris menunjukkan bahwa indikator dari variabel kepercayaan yang memiliki nilai rata-rata terkecil yaitu dari indikator L321 yaitu lengkap dengan nilai sebesar 3.74 yang direfleksikan dengan item Fasilitas berkuliah di Program Studi Manajemen Fakultas Ekonomi dan Bisnis Universitas Budi Luhur Universitas Budi Luhur sangat lengkap, masih di persepsikan rendah oleh responden. Penelitian ini tidak sejalan dengan penelitian yang dilakukan oleh Tumbel (2016) menyatakan bahwa kepercayaan berpengaruh terhadap loyalitas, sedangkan penelitian yang dilakukan oleh Harumi (2016) menyatakan bahwa kepercayaan berpengaruh terhadap loyalitas. Kemudian Hairany dan Sangen (2014) melalukan penelitian dengan hasil bahwa kepercayaan berpengaruh signifikan positif terhadap loyalitas. Penelitian yang dilakukan oleh Bahrudii dan Zuhro (2015) menunjukkan bahwa kepercayaan berpengaruh terhadap loyalitas.

Hasil analisa menunjukkan bahwa perceived value tidak berpengaruh terhadap loyalitas mahasiswa pada mahasiswa di Prodi Manajemen Fakultas Ekonomi dan Bisnis UBL. Fakta empiris menunjukkan bahwa indikator dari variabel perceived value yang memiliki nilai rata-rata terkecil yaitu dari indikator PVM332 yaitu price/ value for money dengan nilai sebesar 3.48 yang direfleksikan dengan item Biaya yang dibayarkan untuk berkuliah di Program Studi Manajemen Fakultas Ekonomi dan Bisnis Universitas Budi Luhur sesuai dengan fasilitas yang diberikan, masih di persepsikan rendah oleh responden. Penelitian ini tidak sejalan dengan penelitian yang dilakukan oleh Ishaq (2012); Auka (2012); dan Chen dan Tsai (2008). Menunjukkan nilai yang diterima pelanggan berpengaruh secara signifikan terhadap loyalitas pelanggan.

Hasil analisa menunjukkan bahwa kepuasan mahasiswa terhadap loyalitas mahasiswa pada mahasiswa di Prodi Manajemen Fakultas Ekonomi dan Bisnis UBL, Jakarta. Fakta empiris menunjukkan bahwa indikator dari variabel kepuasan mahasiswa yang memiliki nilai rata-rata terbesar yaitu senang dengan nilai sebesar 4.12 yang diinterpretasikan dengan item saya senang berkuliah di Prodi Manajemen Fakultas Ekonomi dan Bisnis UBL sudah di persepsikan baik oleh responden dan responden merasa puas. Penelitian ini sejalan dengan penelitian yang dilakukan oleh Irmawati (2016) menyatakan bahwa salah satu indikator dari pengelolaan Universitas yang profesional yaitu apabila lembaga tersebut mampu memberikan pelayanan publik yang berkualitas, salah satunya adalah pelayanan akademik yang berkaitan dengan kelangsungan perkuliahan dan berhubungan secara langsung dengan mahasiswa, melalui perbaikan berbagai pelayanan tersebut diharapkan memberikan kemudahan dan kenyamanan mahasiswa dalam mengikuti proses pembelajaran; Kurniawati (2014), menunjukkan bahwa kepuasan konsumen berpengaruh positif dan signifikan terhadap loyalitas pelanggan. Penelitian yang dilakukan oleh Kemudian penelitian yang dilakukan oleh Haryati Hatta (2017) menunjukkan bahwa kepuasan berpengaruh terhadap loyalitas. Indarto et al., (2018) pada risetnya menyatakan kepuasan berpengaruh terhadap loyalitas. Dan penelitian yang dilakukan oleh Sumertana (2016) membuktikan bahwa kepuasan berpengaruh terhadap loyalitas. 
Berdasarkan penelitian yang telah dilakukan, hasil penelitian menunjukkan bahwa kualitas pelayanan, kepercayaan, perceived value dan kepuasan mahasiswa memiliki pengaruh dan positif terhadap loyalitas mahasiswa pada mahasiswa di Program Studi Manajemen, Fakultas Ekonomi dan Bisnis, Universitas Budi Luhur, Jakarta. Bisa dilihat pada Tabel 2, terdapat nilai (Sig.) yaitu 0.000 di mana nilai tersebut lebih kecil dari tingkat kesalahan yang ditetapkan yaitu 0.05 (0.000 kurang dari 0.05). Sehingga dapat disimpulkan bahwa model regresi linear yang di estimasi layak digunakan untuk menjelaskan pengaruh kualitas pelayanan, kepercayaan, perceived value, dan kepuasan mahasiswa terhadap loyalitas mahasiswa pada mahasiswa di Program Studi Manajemen Fakultas Ekonomi dan Bisnis di Universitas Budi Luhur, Jakarta.

Penelitian ini sejalan dengan penelitian yang dilakukan oleh Irmawati (2016) menyatakan bahwa melalui perbaikan berbagai pelayanan tersebut diharapkan memberikan kemudahan dan kenyamanan mahasiswa dalam mengikuti proses pembelajaran. Penelitian yang dilakukan oleh Starini (2013), Sumetana (2016) dan Putri (2017) menyatakan bahwa kualitas pelayanan berpengaruh positif dan signifikan terhadap loyalitas pelanggan. Kemudian penelitian yang dilakukan oleh Tumbel (2016), Harumi (2016), Hairany dan Sangen (2014) serta Bahrudin dan Zuhro (2015) menyatakan bahwa kepercayaan berpengaruh terhadap loyalitas. Penelitian yang dilakukan oleh Ishaq (2012); Auka (2012); dan Chen dan Tsai (2008) menunjukkan nilai yang diterima pelanggan berpengaruh secara signifikan terhadap loyalitas pelanggan. Kurniawati (2014), Haryati Hatta (2017), Indarti et al., (2018) serta Sumertana (206) menunjukkan bahwa kepuasan konsumen berpengaruh positif dan signifikan terhadap loyalitas pelanggan.

\section{PENUTUP}

Berdasarkan analisis dan pembahasan pada bagian sebelumnya, maka dapat ditarik kesimpulan sebagai berikut: Kualitas pelayanan tidak berpengaruh terhadap loyalitas mahasiswa; Kepercayaan tidak berpengaruh terhadap loyalitas mahasiswa; Perceived quality tidak berpengaruh terhadap loyalitas mahasiswa; Kepuasan mahasiswa berpengaruh terhadap loyalitas mahasiswa; Secara simultan kualitas pelayanan, kepercayaan, perceived value dan kepuasan mahasiswa berpengaruh terhadap loyalitas mahasiswa.

Saran bagi penelitian yang akan datang adalah hendaknya dilakukan uji pra-sampling kuesioner, karena dalam penelitian ini masih terdapat indikator-indikator yang bersifat ganda yaitu satu indikator dapat mengukur dua variabel; Sampel dalam penelitian ini hanya berasal dari satu institusi saja, sehingga penelitian selanjutnya hendaknya dapat dilakukan dengan memperbanyak sampel dengan memperluas jumlah institusi yang dijadikan objek penelitian; Penelitian ini dilakukan pada lembaga jasa seperti institusi perguruan tinggi. Masih perlu dilakukan penelitian kembali pada populasi yang berbeda, misalnya perusahaan jasa, sektor perdagangan dan manufaktur, atau lembaga keuangan lain selain di perbankan; Alat analisis yang digunakan dalam penelitian ini adalah SEM-PLS, sehingga penelitian yang akan datang disarankan untuk mengolah menggunakan alat analisis yang lain seperti SEM_AMOS, SPSS dan lain-lain.

\section{DAFTAR PUSTAKA}

Auka, D.O. (2012). Service Quality, Satisfaction, Perceived Value and Loyalty Among Customers in Commercial Banking in Nakuru Municipality, Kenya. African Journal of Marketing Management. 4(5), 185-203.

Bahrudin, M., Zuhro, S. (2015). Pengaruh Kepercayaan Dan Kepuasan Pelanggan Terhadap Loyalitas Pelanggan. Jurnal Bisnis Dan Manajemen Islam. 3(1), Juni. 1-17. 
Chen, C-F \& M-H, Tsai. (2008). Perceived Value, Satisfaction, and Loyalty of TV Travel Product Shopping: Involvement as a Moderator. Journal of Tourism Management. 29:1166-1171.

Erwin, S.,Tumpal, J.R. (2014). Kontribusi Kualitas Jasa, Kepercayaan dan Kepuasan Konsumen Dalam Menciptakan Loyalitas Konsumen. Jurnal Manajemen. 13(2). 85-191. ISSN.1907-0896.

Harumi, S.D. (2016). Pengaruh Kepercayaan dan Kepuasan Pelanggan Terhadap Loyalitas Pelanggan di Perusahaan Seiko Laundry Medan. Analitika. 8(2). Desember. P-ISSN: 2085-6601, e-ISNN: 2502-4590. 115-128.

Haryani, H.I. (2017). Feature, Nilai, Kepuasan dan Loyalitas Pelanggan. Jurnal Riset Manajemen Dan Bisnis. 7(1), Februari, 45-52. ISSN.2527-7502.

Indarto, E W,. Suroso, I dan Sudaryanto. (2018). Pengaruh Citra Merek dan Atribut Produk Terhadap Kepuasan Konsumen dan Loyalitas Konsumen. Journal of Applied Management (JAM), 16(3), September.

Kurniawan, D. (2013). Pengaruh Kualitas Layanan, Kualitas Produk Dan Nilai Nasabah Terhadap Kepuasan Dan Loyalitas Nasabah (Studi Kasus Bank BPD DIY Syariah). Yogyakarta: Skripsi.

Kurniawati, D. dkk. (2014). Pengaruh Citra Merek dan Kualitas Produk Terhadap Kepuasan dan Loyalitas Pelanggan. Jurnal Administrasi Bisnis (JAB), 14(2).

Kotler, P. and Amstrong, G. (2007). Marketing an Introduction (Eight Edition). Pearson Prentice Hall. New Jersey.

Lee, H.S. (2010). Factors Influencing Customer Loyalty of Mobile Phone Service: Empirical Evidence from Koreans. Journal of Internet Banking and Commerce. 15(2), $1-14$.

Putra, IKM., dan Yasa, NK., (2015). Pengaruh Kualitas Pelayanan Terhadap Kepuasan Mahasiswa, Citra, dan Positive Word of Mouth Politeknik Negeri Bali. Jurnal Bisnis dan Kewirausahaan. 11 (1): $90-102$.

Putri, Y.L. (2017). Pengaruh Kualitas Pelayanan Terhadap Loyalitas Pelanggan dengan Kepuasan Sebagai Variabel Intervening (Studi Persepsi pada Pelanggan Dian Com Ambarawa). Among Makarti. 10(19).Juli. 71-90.

Setiyati, R. (2013). Persepsi Dan Kepuasan Mahasiswa Terhadap Pelayanan Administrasi Akademik Di Universitas Indonusa Esa Unggul, Jakarta. Forum Ilmiah. 20(1). Januari. 48-63.

Starini, H. (2013). Pengaruh Kualitas Pelayanan terhadap Loyalita Konsumen dengan Kepuasan sebagai Variabel Mediasi (Studi PadaToko Basuki Jaya Yogyakarta). Skripsi Tidak Diterbitkan. UniversitasNegeri Yogyakarta.

Sumertana, I.W. (2016). Pengaruh Kualitas Pelayanan Terhadap Loyalitas Pelanggan Dengan Kepuasan Pelanggan Sebagai Variabel Intervening pada Water Park Seririt Singaraja Tahun 2014-2015. Jurnal Program Studi Pendidikan Ekonomi (JPPE). 7(2).

Tanish, M.I. (2015). The Effect of Service Quality, Customer Satisfaction, Trust and Perceived Value Towards Customer Loyalty. Jurnal Dinamika Manajemen. 6(1), 55-61.

Tumbel, A. (2016). Pengaruh Kepercayaan dan Kepuasan Terhadap Loyalitas Nasabah pada PT Bank BTPN Mitra Usaha Rakyat Cabang Amurang Kabupaten Minahasa Selatan. Jurnal LPPM Bidang EkoSosBudKum. 3(1). Edisi Mei. 64-79.

Zahir, A. \& Saddang, S. (2016). Analisis Kualitas Layanan Akademik Universitas Cokroaminoto Palopo. Prosiding Seminar Nasional. 2(1). ISSN:2443-1109. 